University of Nebraska - Lincoln

DigitalCommons@University of Nebraska - Lincoln

Agronomy \& Horticulture -- Faculty Publications

Agronomy and Horticulture Department

November 1997

\title{
Morphological Development of Switchgrass as Affected by Planting Date
}

\author{
Alexander J. Smart \\ University of Nebraska-Lincoln \\ Lowell E. Moser \\ University of Nebraska-Lincoln, Imoser1@unl.edu
}

Follow this and additional works at: https://digitalcommons.unl.edu/agronomyfacpub

Part of the Plant Sciences Commons

Smart, Alexander J. and Moser, Lowell E., "Morphological Development of Switchgrass as Affected by Planting Date" (1997). Agronomy \& Horticulture -- Faculty Publications. 66.

https://digitalcommons.unl.edu/agronomyfacpub/66

This Article is brought to you for free and open access by the Agronomy and Horticulture Department at DigitalCommons@University of Nebraska - Lincoln. It has been accepted for inclusion in Agronomy \& Horticulture -Faculty Publications by an authorized administrator of DigitalCommons@University of Nebraska - Lincoln. 


\title{
Morphological Development of Switchgrass as Affected by Planting Date
}

\author{
Alexander J. Smart* and Lowell E. Moser
}

\begin{abstract}
Late-spring and early-summer plantings of warm-season grasses often fail, due to dry soil conditions and competition from annual grass and broadleaf weeds. The objective of this study was to compare the morphological development of switchgrass (Panicum virgatum L.) planted in early, mid, and late spring in eastern Nebraska. This study was conducted in 1994 and 1995 at Lincoln, NE, on a Kennebec silt loam (fine-silty, mixed, mesic Cumulic Hapludolls). 'Blackwell' and 'Trailblazer' switchgrass were planted in mid-March, late April, and late May using a single-row, precision grass-seed cone planter to a depth of 0.6 to $1.3 \mathrm{~cm}$ at 98 pure live seed per linear meter of row in a split-plot design. Twenty seedlings from each plot were excavated to a depth of $20 \mathrm{~cm}$ with a spade. Seedling morphological parameters measured were mean stage count root (MSCR) and shoot (MSCS), leaf area, shoot weight, and primary and adventitious root weight. Plots were sampled every $10 \mathrm{~d}$ following the first sample date. In 1994, seedlings from the March planting date were more advanced morphologically in MSCR and MSCS, had accumulated 2.5 times more leaf area, and about 3 times more shoot and adventitious root mass than the April planting date when sampled from late May to late June. In 1995, seedlings from the March planting date generally were more advanced morphologically in root and shoot development, had accumulated 2 to 12 times more leaf area, had 2 to 10 times more shoot mass, and had 2 to 33 times more adventitious root mass than the April or May planting dates at the sample periods from early June to mid-July. We suggest that switchgrass should be planted in early spring instead of in late April and May, as suggested by previous research.
\end{abstract}

$\mathrm{S}^{\mathrm{w}}$ WITCHGRASS is a native warm-season perennial grass that is commonly grown throughout the central Great Plains. Late-spring and early-summer plantings often fail, due to dry soil conditions and competition from annual grass and broadleaf weeds. Both soil moisture and weed competition are affected by planting date. Early planting may take advantage of the greater amount and more even distribution of rainfall in late spring and early summer compared with midsummer. This could result in better adventitious root formation, which is important for seedling survival (Hyder et al., 1971; Ries and Svejcar, 1991). Timing of emergence and subsequent adventitious root formation, which is critical for seedling survival, depends on adequate soil surface moisture (Wilson and Briske, 1979; Newman and Moser, 1988). In Nebraska, Newman and Moser (1988) reported that switchgrass seedlings planted on 1 June did not form adventitious roots until late July, because there was little rainfall from 3 to 6 wk after planting. In the following year, however, switchgrass seedlings planted on 2 June had numerous adventitious roots by mid-July, because the soil surface was wet for several days early in the 4- to 6-wk period after planting.

Dep. of Agronomy, Univ. of Nebraska-Lincoln, 279 Plant Sci., Lincoln, NE 68583. Nebraska Agric. Exp. Stn. Journal Series no. 11793. Received 28 Dec. 1996. *Corresponding author (agro101@unlvm.unl. edu).

Published in Agron. J. 89:958-962 (1997).
Switchgrass often has a large percentage of dormant seed. An additional advantage of early planting may be reduced seed dormancy, which results from exposing seed to cool moist conditions in the seedbed. Wet prechilling seed at $5^{\circ} \mathrm{C}$ for $2 \mathrm{wk}$ significantly increased germination percentage (AOSA, 1995; Emal and Conard, 1973; Zarnstorff et al., 1994). Our objective was to compare the morphological development of switchgrass planted in early, mid, and late spring in eastern $\mathrm{Ne}$ braska.

\section{MATERIALS AND METHODS}

This study was conducted in 1994 and 1995 on the East Campus of the University of Nebraska-Lincoln on a Kennebec silt loam soil (fine-silty, mixed, mesic Cumulic Hapludolls). The site was used for other seedling studies in 1992 and 1993. No soil amendments were added, and the area was moldboardplowed each fall. Bare soil temperature at the $10-\mathrm{cm}$ depth and rainfall data were obtained from the Institute of Agriculture and Natural Resources weather monitoring station approximately $1 \mathrm{~km}$ from the study site.

Experimental design was a randomized complete block, with four replicates. Treatments were arranged in a split-plot design. Blackwell and Trailblazer switchgrass cultivars were whole plots, and dates of planting were subplots. Whole plots were six rows, $12.1 \mathrm{~m}$ long and spaced $0.9 \mathrm{~m}$ apart. Subplots were two full rows of the whole plot. The sampling unit was a group of 20 seedlings excavated from the subplot. The seedbed was prepared in March of both years with a spring-tooth harrow. Before each planting date, rows were hand-raked to smooth the surface and break up clods. In 1994, the planting dates were 16 March, 18 April, and 24 May; in 1995, the planting dates were 21 March, 24 April, and 26 May. Seed was planted with a single-row, precision grass-seed cone planter (Kincaid Equipment Manufacturing, Haven, KS) to a depth of 0.6 to $1.3 \mathrm{~cm}$ at 98 pure live seed per linear meter of row. Weeds were controlled by hand-weeding.

Twenty seedlings from each plot were excavated to a depth of $20 \mathrm{~cm}$ with a spade. Most soil was removed from the roots in the field, but roots were gently washed in the lab to remove remaining soil. Nearly all of the root mass was recovered with this technique. Samples were then stored in plastic bags at $5^{\circ} \mathrm{C}$ until morphological staging and plant component weight was determined. Seedling morphology was quantified as to MSCR and MSCS using the index developed by Moser et al. (1993) (Table 1), where mean stage count equals the growth stage index value multiplied by the number of seedlings in that stage and summed over all stages from 1 to 8 and divided by the total number of seedlings. Additionally, leaf area, shoot weight, and primary root weight and adventitious root weight were measured to quantify seedling development. Plots were sampled every $10 \mathrm{~d}$ following the first sample date, which usually occurred within $10 \mathrm{~d}$ after emergence at the S1 or S2 shoot stage (Table 1). For each planting date, the 20 -seedling sample was taken from two 2.4-m adjacent segments of the two rows from the subplot. Leaf area was measured on the 20 -seedling sample by tearing the leaf blades at the collar and feeding the blades through a portable area meter (Model LI-

Abbreviations: MSCR, mean stage count root; MSCS, mean stage count shoot 
Table 1. Growth stages, numerical indices, and descriptions for staging grass seedling shoots and roots. $\dagger$

\begin{tabular}{|c|c|c|}
\hline Stage & Index & Description \\
\hline \multicolumn{3}{|l|}{ Shoot } \\
\hline S1 & 1.0 & Coleoptile emerged from seed \\
\hline S2 & 2.0 & Emergence of leaf from coleoptile \\
\hline $\mathbf{S 3}$ & 3.0 & Appearance of collar or ligule of 1 st leaf \\
\hline S4 & 4.0 & Appearance of collar or ligule of 2 nd or $3 \mathrm{rd}+$ leaf \\
\hline S5 & 5.0 & Appearance of collar or ligule of 4 th to $6 \mathrm{th}+$ leaf \\
\hline S6 & 6.0 & Appearance of 1st secondary tiller \\
\hline S7 & 7.0 & Appearance of 2nd secondary tiller \\
\hline S8 & $\mathbf{8 . 0}$ & Appearance of 3rd secondary tiller \\
\hline \multicolumn{3}{|r|}{ 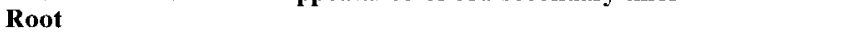 } \\
\hline $\mathbf{R 1}$ & 1.0 & Radicle emergence from seed \\
\hline $\mathbf{R 2}$ & 2.0 & $\begin{array}{l}\text { Primary root branching and/or seminal root } \\
\text { formation }\end{array}$ \\
\hline $\mathbf{R 3}$ & 3.0 & Appearance of 1st adventitious root \\
\hline $\mathbf{R 4}$ & 4.0 & Appearance of 2 to 3 adventitious roots \\
\hline $\mathbf{R 5}$ & 5.0 & Appearance of 4 to 6 adventitious roots $\frac{7}{t}$ \\
\hline R6 & 6.0 & Appearance of 7 to 10 adventitious roots \\
\hline $\mathbf{R} 7$ & $\mathbf{7 . 0}$ & Appearance of $\geq 10$ adventitious roots $;$ \\
\hline $\mathbf{R 8}$ & 8.0 & Appearance of 1st true rhizome \\
\hline
\end{tabular}

$\dagger$ From Moser et al. (1993).

$¥$ The number of leaves or roots in these stages can be changed, providing flexibility to accommodate a wide range of developmental variation among species.

3000, LI-COR, Lincoln, NE). Analysis of variance (SAS, 1988) was performed on all variables within a common sampling date. Means were separated using Fisher's protected least significant difference at $\alpha=0.05$ (Steel and Torrie, 1980).

\section{RESULTS \\ Climatological Summary}

In 1994, rainfall was fairly evenly distributed throughout spring and summer (Fig. 1). In 1995, however, there was a major wet period that lasted until early June and then a long dry period that lasted through the summer, with only one major rainfall event (in early July). Although fluctuating, soil temperature in 1994 gradually increased after thawing on 1 March. In 1995, the soil remained frozen until about $7 \mathrm{March}$, then quickly warmed to $10^{\circ} \mathrm{C}$ and stayed near 10 to $15^{\circ} \mathrm{C}$ until midMay. Spring soil temperature was cooler in 1995 than 1994 because of cool, wet conditions in May 1995. Summer soil temperatures were warmer in 1995 than in 1994 because of the hot, dry conditions in 1995.

\section{Shoot Development}

There was poor emergence of Blackwell switchgrass from the May 1994 planting, so this cultivar was excluded from the analysis due to an insufficient number of seedlings. In 1994, seedlings from the March planting generally had greater MSCS, had more leaf area, and were heavier than seedlings from the April or May plantings when sampled from 23 May to 22 June (Fig. 2). Seedlings from the April planting had greater MSCS, had more leaf area, and were heavier than those from the May planting.

At several sample dates there were interactions between the cultivars and planting date for MSCS, leaf area, and shoot weight. On 2 June, Trailblazer seedlings were 0.8 MSCS units more advanced than Blackwell for the March planting date and 1.7 units greater for the April planting date. On 22 June, the difference in leaf

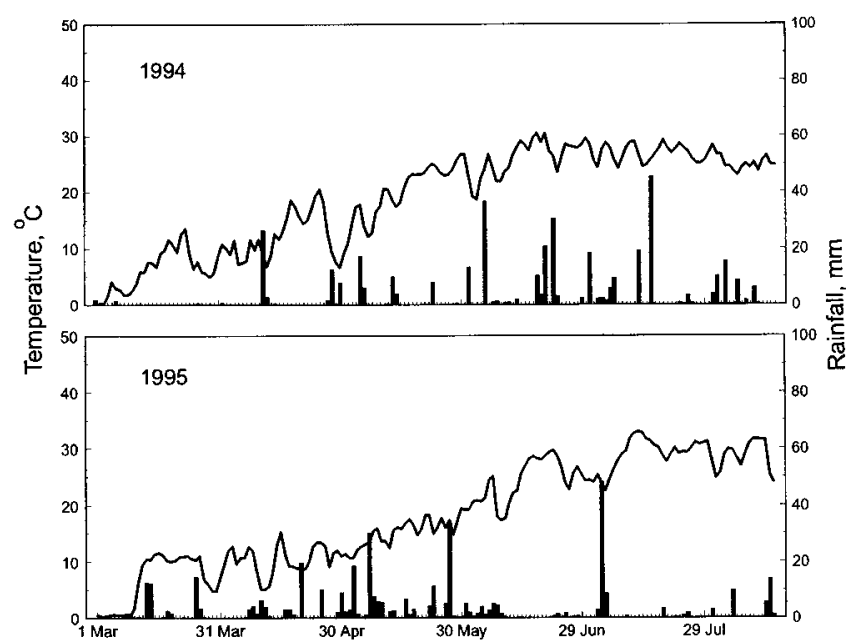

Fig. 1. Mean soil temperature (line) at the $10-\mathrm{cm}$ depth and daily rainfall (bars) at the Univ. of Nebraska-Lincoln East Campus during the 1994 and 1995 field seasons.

area was $1360 \mathrm{~cm}^{2}$ greater for March-planted Trailblazer seedlings than for Blackwell seedlings.

However, Trailblazer seedlings had only $427 \mathrm{~cm}^{2}$ greater leaf area than Blackwell for the April planting date. On 22 June, there was a greater difference between Trailblazer and Blackwell shoot weights with the March than with the April plantings. Trailblazer generally was more advanced morphologically than Blackwell at most seeding dates. Trailblazer seedlings had more accumulated leaf area than Blackwell seedlings on 3 May, 2 June, and 1 July, and Trailblazer shoots weighed more than Blackwell shoots on 22 June and 1 July.

In 1995, March-planted seedlings generally had greater MSCS, more leaf area, and were heavier than the April or May planting dates during the sample periods of 7 June to early or mid-July (Fig. 2). However, seedlings planted in April were similar to those planted in May in MSCS, leaf area, and shoot weight during the same period. There were fewer interactions in 1995 than in 1994 for the different sampling dates among the two varieties and planting dates. On 17 July, leaf area was greater for Blackwell seedlings planted in March than for Trailblazer seedlings, but was similar for other planting dates. Shoot weight was much greater for Blackwell seedlings planted in March than for Trailblazer seedlings sampled on 19 June and 17 July, but for other planting dates shoot weights were similar. The two cultivars were similar in MSCS on all sampling dates.

\section{Root Development}

In 1994, MSCR and adventitious root weight were greater for March plantings than for April or May plantings during the 23 May to 22 June sampling period (Fig. 3 ). Primary root weight was very small and did not differ significantly. April plantings generally had greater MSCR and adventitious root weight than May plantings. There were no interactions with cultivars and planting dates for sampling dates in 1994. In 1994, the two cultivars generally developed in similar patterns with a few 

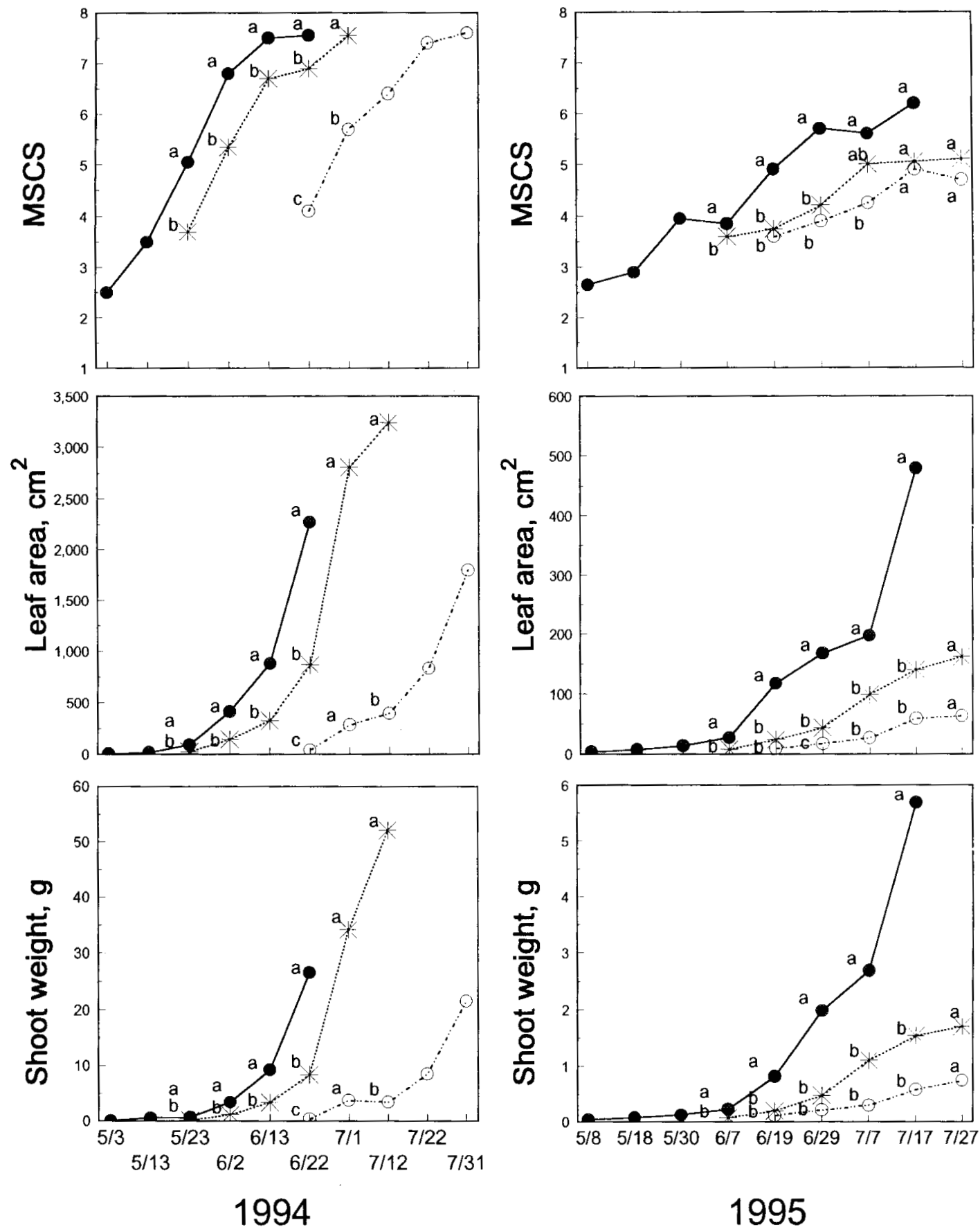

1995

Fig. 2. Mean stage count shoot (MSCS), leaf area, and shoot weight of 20 switchgrass seedlings sampled throughout the growing season from three planting dates (solid circles, March; stars, April; open circles, May) in 1994 and 1995 at Lincoln, NE. Within sampling dates, means accompanied by different letters are significant at $P=\mathbf{0 . 0 5}$. Note that $y$-axis scales differ between years for leaf area and shoot weight.

exceptions. Trailblazer had greater MSCR than Blackwell seedlings on 2 June.

At the 7 June to 17 July sampling periods in 1995 , seedlings from the March planting date generally had a greater MSCR and a greater adventitious root mass than seedlings from the April or May planting dates (Fig. 3). Seedlings from the April planting were more advanced than those from May plantings during the 19 June to 7 July sampling period. There were no interactions in 1995 for the different sampling dates between cultivars and planting dates for MSCR and primary root weight. However, adventitious root weight was larger for both March and April planting dates for Blackwell seedlings than Trailblazer seedlings on 7 June. In 1995, the two cultivars had similar MSCR values on common days of the year.

\section{DISCUSSION}

Early plantings, especially March, produced seedlings that were more advanced in morphological development (MSCS and MSCR) and had greater shoot and 

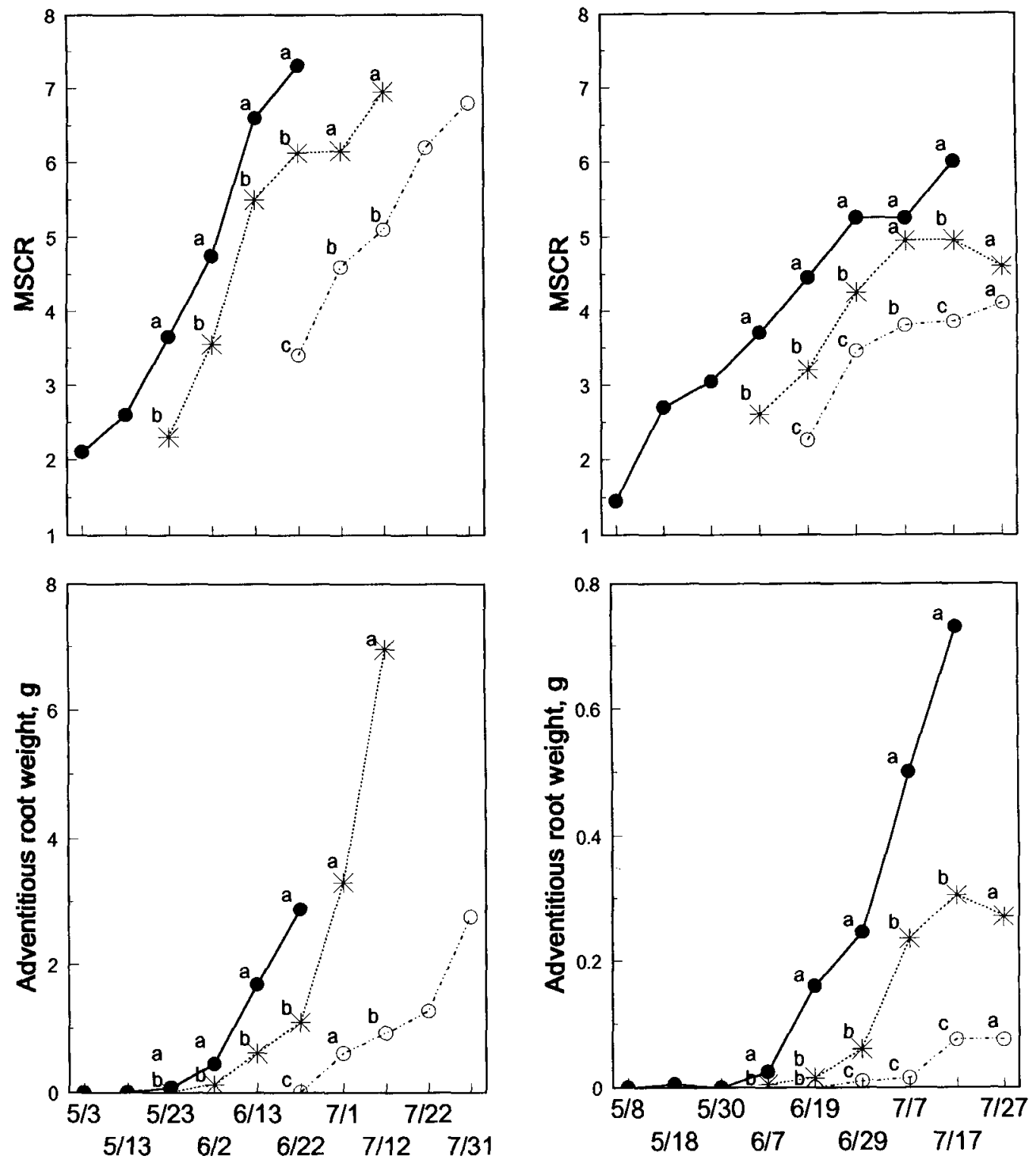

1994

1995

Fig. 3. Mean stage count root (MSCR) and adventitious root weight of 20 switchgrass seedlings sampled throughout the growing season from three planting dates (solid circles, March; stars, April; open circles, May) in 1994 and 1995 at Lincoln, NE. Within sampling dates, means accompanied by different letters are significant at $P=0.05$. Note that $y$-axis scales differ between years for root weight.

adventitious root biomass at the summer sampling dates compared with the May planting. Seedlings from May plantings were behind in development and produced less shoot and root biomass. Seedlings from May plantings did not catch up in MSCS and MSCR to the earlier planted seedlings until early July in 1994 and late July in 1995 and never caught up in biomass. In Iowa, dry matter yields were highest for April vs. May and June planting dates for the seeding year and for two years after seeding (Vassey et al., 1985).

Blue grama [Bouteloua gracilis (Kunth) Lag. ex Griffiths] was considered established when two adventitious roots penetrated to a depth of $10 \mathrm{~cm}$ and there were two tillers per plant (Ries and Svejcar, 1991). According to the staging index used in this study (Moser et al., 1993), those seedlings would be at R4 and S6. In 1994, the March, April, and May seedlings reached the R4 stage by late May, early June, and late June, respectively. In this study, there was enough rainfall spread evenly that the seedling survival was certain for seedlings planted at all three times. However, in 1995 seedlings planted in March, April, and May did not reach the R4 stage until mid-June, late June, and mid-July, respectively. In 1995, if there had not been a 3-d period of rain in early July, the May planting could have failed. Adventitious root formation will not occur if soil surface moisture is not adequate (Newman and Moser, 1988). The soil surface must be moist for 3 to $5 \mathrm{~d}$ before adven- 
titious roots will form (Hyder et al., 1971; McGinnies, 1973; Wilson and Briske, 1979). Therefore, the benefit of planting early (March or April), especially in 1995, was realized by taking advantage of the higher probability of moist soil surface existing for 3 to $5 \mathrm{~d}$ earlier in the season vs. the late planting date. Weather records indicate that the probability of receiving 15 and $25 \mathrm{~mm}$ of precipitation in 1-wk intervals at Lincoln, NE, is highest in mid-June (55 and $40 \%$, respectively) and drops by 20 percentage points in July (Colville and Myers, 1965, p. 13). In 1994, seedlings from March and April plantings had a MSCR of 4.0 by early June, compared with late June for the May planting date. In 1995, seedlings from the March and April plantings had a MSCR of 4.0 by late June, compared with late July for the May planting date.

March and April plantings also could have an affect on reducing some dormant seed and provide favorable germination conditions, because the temperature near the soil surface are likely to remain under $20^{\circ} \mathrm{C}$ through April, and in May the temperature typically fluctuates near $30 / 20^{\circ} \mathrm{C}$ day/night temperatures (Fig. 1). Unchilled Blackwell switchgrass seeds have been shown to have maximum germination at temperatures between 12 and $15^{\circ} \mathrm{C}$ (Hsu et al., 1985). Early planting dates could therefore provide a favorable germination environment for unchilled switchgrass seed.

We suggest that switchgrass and possibly other perennial warm-season grasses should be planted in early spring, rather than the late April and May planting dates suggested by previous research (Hsu and Nelson, 1986a,b; Vassey et al., 1985). By planting early, the risk of unfavorable moisture conditions is reduced during the period of adventitious root development, which is necessary for successful establishment. In addition, there may be an added benefit in reducing a portion of the dormant seed and so resulting in a higher germination rate.

\section{REFERENCES}

Association of Official Seed Analysts (AOSA). 1995. Rules for testing seed. J. Seed Technology. Vol. 16. No. 3.

Colville, W.L., and R.E. Myers. 1965. Nebraska's precipitation: Its patterns and probabilities. Misc. Publ. 10. Nebraska Agric. Exp. Stn.

Emal, J.G., and E.C. Conard. 1973. Seed dormancy and germination in indiangrass as affected by light, chilling, and certain chemical treatments. Agron. J. 65:383-385.

Hsu, F.H., and C.J. Nelson. 1986a. Planting date effects on seedling development of perennial warm-season forage grasses: I. Field emergence. Agron. J. 78:33-38.

Hsu, F.H., and C.J. Nelson. 1986b. Planting date effects on seedling development of perennial warm-season forage grasses: II. Seedling growth. Agron. J. 78:38-42.

Hsu, F.H., C.J. Nelson, and A.G. Matches. 1985. Temperature effects on germination of perennial warm-season forage grasses. Crop Sci. 25:215-220.

Hyder, D.N., A.C. Everson, and R.E. Bement. 1971. Seedling morphology and seeding failures with blue grama. J. Range Manage. 24:287-292.

McGinnies, W.J. 1973. Effects of date and depth of planting on the establishment of three range grasses. Agron J. 65:120-123.

Moser, L.E., K.J. Moore, M.S. Miller, S.S. Waller, K.P. Vogel, J.R. Hendrickson, and L.A. Maddux. 1993. A quantitative system for describing the developmental morphology of grass seedling populations. p. 317-318. In M.J. Baker et al. (ed.) Proc. Int. Grassl. Congr., 17th, Palmerston North, New Zealand. 8-21 Feb. 1993. NZ Grassl. Assn., Palmerston North, New Zealand.

Newman, P.R., and L.E. Moser. 1988. Grass seedling emergence, morphology, and establishment as affected by planting depth. Agron. J. 80:383-387.

Ries, R.E., and T.J. Svejcar. 1991. The grass seedling: When is it established? J. Range Manage. 44:574-576.

SAS Institute. 1988. SAS user's guide: Statistics. Version 6.03 ed. SAS Inst., Cary, NC.

Steel, R.G.D., and J.H. Torrie. 1980. Principles and procedures of statistics: A biometrical approach. 2nd ed. McGraw-Hill, New York.

Vassey, T.L., J.R. George, and R.E Mullen. 1985. Early-, mid-, and late-spring establishment of switchgrass at several seeding rates. Agron. J. 77:253-257.

Wilson, A.M., and D.D. Briske. 1979. Seminal and adventitious root growth of blue grama seedlings on the central plains. J. Range Manage. 32:209-213.

Zarnstorff, M.E., R.D. Keys, and D.S. Chamblee. 1994. Growth regulator and seed storage effects on switchgrass gcrmination. Agron. J. 86:667-672. 